\title{
ANALISIS FAKTOR DEMOGRAFI DAN ERGONOMI TERHADAP KEJADIAN GEJALA FISIK SICK BUILDING SYNDROM (SBS) PADAPEGAWAI GEDUNG REKTORAT UMI KOTA MAKASSAR
}

Novi Poni Harwani ${ }^{1}$, Sartika Fathir Rahman ${ }^{2}$, dan Baharuddin Sunu ${ }^{3}$

1,2,3Bagian Kesehatan Lingkungan, Politeknik Kesehatan Muhammadiyah Makassar noviponikero@gmail.com

\section{ABSTRACT}

The Environmental Protection Agency (EPA) in 1991 said this syndrome was related to the time someone spent in a building, but the symptoms were not specific and the cause could not be identified. Sick Building Syndrome is a condition associated with complaints of discomfort such as dizziness, nausea, dermatitis, irritation of the throat, nose, eyes and respiratory tract, coughing, difficulty concentrating, nausea in odors, aching / aching muscles and fatigue (tiredness) Nasri, et al, 1998). The purpose of this study was to determine the demographic factors (age, sex, years of service, smoking, psychosocial conditions) and Ergomy on the physical symptoms of Sick Building Syndrome in the Umi Rectorate Building. This type of research used in this research is descriptive-analytic research, using a cross-sectional design. The population in this study was all employees in the Umi Rectorate Building in Makassar City amounting to 113 employees. The results of the study are of the six variables age, sex, years of service, smoking, psychosocial conditions, and ergonomics, namely gender and ergonomy, which means that they have a significant relationship with Sick Building Syndrome complaints. Male sex I suffer more SBS than women. The results obtained by the value of $p=0.013<0.05$ which means there is a meaningful relationship. The results of the study of the sex of men who experienced SBS were 20 employees (38.5\%) and female sex did not experience SBS as many as 25 employees (64.1\%). The results showed that employees who experienced abnormal ergonomic positions and suffered from SBS more with 32 respondents (61.5\%) compared to employees who experienced normal ergonomic positions with 13 employees (33.3\%) results so that there was a value $p=0.007<0.05$ which means that there is a significant relationship between ergonomics with Sick Building Syndrome in Menara UMI Building.

Keywords: Demographic Factors, Ergonomics, Sick Building Syndrome

\section{ABSTRAK}

Environmental Protection Agency (EPA) tahun 1991 mengatakan sindrom ini timbul berkaitan dengan waktu yang dihabiskan seseorang dalam sebuah bangunan, namun gejalanya tidak spesifik dan penyebabnya tidak bisa dindetikasi. Sick Building Syndrome adalah suatu kondisi yang berhubungan dengan keluhan ketidaknyamanan seperti pusing, mual, dermatitis, iritasi saluran tenggorakan, hidung, mata, dan saluran pernapasan, batuk, sulit konsentrasi, mual terhadap bau-bau, sakit/pegal otototot dan letih (Nasri, dkk, 1998). Tujuan Penelitian ini adalah Untuk mengetahui faktor Demografi (umur, jenis kelamin, masa kerja, merokok, kondisi psikososial) dan Ergomi terhadap gejala fisik kejadian Sick Building Syndrome pada Gedung Rektorat Umi. Jenis penelitian yang digunakan dalam penelitian ini adalah penelitian deskriptif analitik, dengan menggunakan rancangan cross sectional. Populasi pada penelitian ini adalah seluruh pegawai di Gedung Rektorat Umi Kota Makassar berjumlah 113 pegawai. Hasil penelitian yaitu dari keenam variabel umur, jenis kelamin, masa kerja, merokok, kondisi psikososial, dan ergonomi yaitu vaiabel jenis kelamin dan ergomi yang artinya memiliki hubungan yang bermakna dengan keluhan Sick Building Syndrom. Jenis kelamin laki-laki lebih banyak menderita SBS dibanding perempuan. Hasil penelitian didapatkan nilai $p=0,013<0,05$ yang berarti ada hubungan yang bermakna. Hasil penelitian jenis kelamin laki-laki yang mengalami SBS sebanyak 20 pegawai $(38,5 \%)$ dan jenis kelamin wanita tidak mengalami SBS sebanyak 25 pegawai $(64,1 \%)$. Hasil penelitian menunjukkan bahwa pegawai yang mengalami posisi ergonomi tidak normal dan menderita SBS lebih banyak yaitu dengan hasil 32 responden $(61,5 \%)$ di banding pegawai yang mengalami posisi ergonomi normal yaitu dengan hasil 13 pegawai $(33,3 \%)$, sehingga didapatkan nila $\mathrm{p}=0,007<0,05$ yang berarti ada hubungan yang bermakna antara ergonomi dengan Sick Building Syndrom di Gedung Menara UMI.

Kata Kunci : Faktor Demografi, Ergonomi, Sick Building Syndrome

\section{PENDAHULUAN}

Perwujudan kualitas lingkungan yang sehat merupakan bagian pokok di bidang kesehatan. Udara sebagai komponen lingkungan yang penting dalam kehidupan perlu dipelihara dan ditingkatkan kualitasnya sehingga dapat memberikan daya dukungan bagi mahluk hidup untuk hidup secara optimal. Pencemara udara dewasa ini semakin menampakkan kondisi yang sangat memprihatinkan. (Depkes RI, 2004).

Bangunan gedung bertingkat merupakan sarana prasarana yang vital sebagai tempat melakukan segala aktivitas baik untuk sebagai kantor, pusat perbelanjaan, dan sebagainya. Oleh karena itu, gedung bertingkat yang ada saat inipun dibuat semakin modern dengan berbagai fasilitas yang lengkap demi menunjang pesatnya laju pertumbuhan pembangunan. Berbagai kelengkapan fasilitas yang ada terkadang dibuat tanpa mengindahkan kesehatan dan kenyamanan para pekerja yang ada didalamnya. Studi tentang pengukuran kualitas udara di dalam gedung dan sarana transportasi telah meunjukkan bahwa konsentrasi pencemar udara dalam ruangan cenderung lebih tinggi dibandingkan diluar ruangan. Udara di dalam ruangan terdiri dari campuran yang kompleks (NRC, 1991; Spengler dan sexton, 1993; Samet dan Spengler, 2003; Gold, 1992).

Kualitas udara dalam ruang selain dipengaruhi oleh keberadaan agen abiotik juga dipengaruhi oleh agen biotik seperti partikel debu dan mikroorganisme termasuk didalamnnya bakteri, jamur, virus dan lain - lain (Salo, et al 2006 dalam Esi, 2010). Berbagai keluhan dan gejala yang timbul saat seseorang berada di dalam gedung dan kondisinya membaik setelah 
keluar dari gedung, kemungkinan karena menderita Sick Building Syndrom (SBS). Kasus SBS tidak menunjukkan gejala yang khas dan secara obyektif tidak dapat diukur. Gejalanya berupa sakit kepala, lesu, iritasi mata, maupun kulit serta berbagai masalah pernapasan. Keluhan lain yang sering dijumpai adalah batuk kering, migrain, sakit kepala, mata memerah, kembung pada bagia perut dan lain sebagainya. Gejala tersebut sulit dicari penyebab yang nyata dan akan dihubungkan dengan SBS apabila terdapat riwayat tinggal di gedung dengan kualitas ruangan yang buruk (Anies, 2004).

Ikatan Ahli Kesehatan Masyarakat Indonesia/ Fakultas Kesehatan Masyarakat Universitas Indonesia (IAKMI/FKMUI) melakukan penelitian terhadap 350 karyawan dari 18 perusahaan di wilayah DKI Jakarta pada tahun 2008, berdasarkan hasil penelitian tersebut karyawan yang bekerja di dalam gedung perkantoran mengalami SBS (Guntoro, 2008). Beberapa penelitian tentang SBS menunjukkan bahwa Faktor Demografi seperti umur, jenis kelamin, status gizi, serta gaya hidup berpengaruh terhadap kejadian SBS. Penelitian yang dilakukan oleh NIOSH tahun 1980 menyatakan bahwa umur berhubungan dengan peningkatan kejadian SBS karena umur berkaitan dengan daya tahan tubuh. Semakin tua umur seseorang maka semakin menurun pula daya tahan tubuhnya (NIOSH, 1980). Sedangkan pada penelitian yang dilakukan Esi Lisyastuti tahun 2010 menyatakan bahwa jenis kelamin wanita memiliki resiko lebih besar dibanding pria. Sebanyak $70 \%$ dari jumlah karyawan wanita mengalami SBS (Esi, 2010).

\section{BAHAN DAN METODE}

Penelitian di laksanakan di Gedung Rektorat Umi Kota Makassarn Tahun 2017 dari bulan Februari sampai bulan Agustus. Jenis penelitian yang digunakan dalam penelitian ini adalah penelitian deskriptif analitik, dengan menggunakan rancangan cross sectional. Populasi pada penelitian ini adalah seluruh pegawai di Gedung Rektorat Umi Kota Makassar berjumlah 113 pegawai. Penarikan sampel dilakukan dengan menggunakan metode proporsional random sampling. Sehingga di dapatkan hasil dengan dari penentuan rumus Lameshow sebanyak 91 sampel. Pemilihan sampel tersebut diambil dengan menggunakan rancangan non-probabilitas/non-acak merupakan cara pengambilan sampel dimana semua elemen populasi belum tentu memiliki peluang yang sama untuk dipilih menjadi anggota sampel, karena ada bagian tertentu secara sengaja tidak dimasukkan dalam pemilihan untuk mewakili populasi. Data penelitian diperoleh dengan mengumpulkan data primer dan data sekunder. Data primer yang diperoleh dari hasil penelitian terhadap pegawai dengan keluhan sick building syndrome dan data sekunder diperoleh dari Gedung Rektorat UMI Kota Makassar.

\section{HASIL}

Tabel 1

Distribusi Berdasarkan Keluhan Sick Building Syndrom Pada Pegawai Di Gedung Menara UMI Kota Makassar

\begin{tabular}{lccccc}
\hline \multirow{2}{*}{ Keluhan SBS } & \multicolumn{4}{c}{ Ya } & \multicolumn{2}{c}{ Tidak } & Total \\
\cline { 2 - 6 } & $\mathrm{n}$ & $\%$ & $\mathrm{n}$ & $\%$ & $\%$ \\
\hline \hline Iritasi mata & 3 & 3,3 & 88 & 96,7 & \\
Iritasi hidung & 3 & 3,3 & 88 & 96,7 & \\
Iritasi tenggorokan & 0 & 0 & 91 & 100,0 & \\
Rasa kering bibir & 15 & 16,5 & 76 & 83,5 & \\
Kulit kering & 22 & 24,2 & 69 & 75,8 & \\
Kulit gatal & 2 & 2,2 & 89 & 97,8 & \\
Merah2 pada kulit & 0 & 0 & 91 & 100,0 & \\
Sakit kepala & 23 & 25,3 & 68 & 74,7 & 91 \\
Sulit berkonsentrasi & 31 & 34,1 & 60 & 65,9 & $(100 \%)$ \\
Rasa lelah & 38 & 41,8 & 53 & 58,2 & \\
Batuk-batuk & 14 & 15,4 & 77 & 94,6 & \\
Pilek & 10 & 11,0 & 81 & 89,0 & \\
Sakit telinga & 0 & 0 & 91 & 100,0 & \\
Radang tenggorokan & 0 & 0 & 91 & 100,0 & \\
Sesak tenggorokan & 2 & 2,2 & 89 & 97,8 & \\
Sesak nafas & 0 & 0 & 91 & 100,0 & \\
Mual dan pusing & 0 & 0 & 91 & 100,0 & \\
\hline \hline Sumber: Data Primer & & & & \\
\hline
\end{tabular}

Sumber: Data Primer

Tabel 2

Distribusi Berdasarkan Penentuan Sick Building Syndrom Pada Pegawai Di Gedung Menara UMI Kota Makassar

\begin{tabular}{ccc}
\hline \hline Penentuan SBS & N & $\%$ \\
\hline \hline Ya & 45 & 49,5 \\
Tidak & 46 & 50,5 \\
\hline \hline Total & $\mathbf{9 1}$ & $\mathbf{1 0 0}$ \\
\hline \hline
\end{tabular}

Sumber: Data Primer

Tabel 3

Hasil Analisis Regresi Logistik Antara Variabel Potensial Dengan Sick Building Syndrom Di Gedung Menara Universitas Muslim Indonesia Kota Makassar

\begin{tabular}{ccccccc}
\hline \hline Covariat & B & S.E & Wald & df & Sig & Exp.(B) \\
\hline \hline Jenis & - & .476 & 6.897 & 1 & .009 & .287 \\
Kelamin & 1.250 & & & & & \\
Ergonomi & 1.350 & .477 & 8.004 & 1 & .005 & 3.856 \\
Constant & -116 & .859 & .018 & 1 & .893 & .891 \\
\hline \hline
\end{tabular}

\section{ANALISIS UNIVARIAT}

Penelitian dilaksanakan di Gedung Menara UMI Kota Makassar. Penelitian ini dilakukan pada 
Jurnal Sulolipu : Media Komunikasi Sivitas Akademika dan Masyarakat

Vol. 20 No. 12020

e-issn : 2622-6960, p-issn : 0854-624X

bulan Juli 2017. Sampel dalam penelitian ini adalah pegawai Gedung Menara.

Hasil penelitian menunjukkan bahwa pegawai yang berjenis kelamin laki-laki lebih besar yaitu sebanyak 52 pegawai $(57,1 \%)$ sedangkan perempuan yaitu sebanyak 39 pegawai $(42,9 \%)$. Berdasarkan kategori umur menunjukkan bahwa pegawai yang berada pada umur $\geq 45$ sebanyak 45 pegawai $(49,5 \%)$ sedangkan umur $<45$ yaitu sebanyak 46 pegawai $(50,5 \%)$.

Berdasarkan masa kerja menunjukkan bahwa lama kerja terbanyak berada pada Masa kerja $\geq 1$ tahun yaitu sebanyak 82 pegawai $(90,1 \%)$ sedangkan pada Masa kerja $<1$ tahun yaitu sebanyak 9 pegawai $(9,9 \%)$. Berdasarkan merokok menunjukkan bahwa pegawai yang merokok sebanyak 19 (20,9\%) pegawai sedangkan pegawai yang tidak merokok sebanyak $72(79,1 \%)$ pegawai. Berdasarkan kondisi psikososial menunjukkan bahwa pada ditribusi kondisi psikososial pegawai gedung menara UMI semuanya tergolong Baik yaitu 91 $(100,0 \%)$ pegawai.

Hasil level ergonomi menunjukkan bahwa tingkatan level tertinggi ergonomi yaitu pada level 3 sebayak $43(47,3 \%)$ pegawai, kemudian level 2 sebanyak $28(30,8 \%)$ pegawai, dan level terendah pada level 1 dan level 4 sebanyak 10 $(11,0 \%)$ pegawai.. Penentuan ergonomi pada pegawai gedung menara Umi yang tidak normal sebanyak $52(57,1 \%)$ pegawai sedangkan yang normal sebanyak $39(42,9 \%)$ pegawai. Berdasarkan tabel 5.8 menunjukkan bahwa keluhan Sick building syndrom yang paling banyak dirasakan oleh pegawai adalah rasa lelah yaitu sebanyak $38(41,8 \%)$ dan keluhan yang tidak pernah dirasakan adalah iritasi tenggorokan, merah-merah pada kulit, sakit telinga, sakit telinga, radang tenggorokan, sesak nafas,mual dan pusing. Pegawai yang mengalami SBS sebanyak 45 (49,5\%) sedangkan pegawai yang tidak SBS yaitu sebanyak $46(50,5 \%)$ pegawai.

\section{ANALISIS BIVARIAT}

Berdasarkan pegawai yang berjenis kelamin laki-laki yang mengalami SBS adalah 20 $(38,5 \%)$ pegawai dan perempuan sebanyak 25 $(64,1 \%)$ pegawai, sedangkan untuk pegawai yang tidak mengalami SBS dengan jenis kelamin laki-laki sebanyak $32(61,5 \%)$ dan perempuan sebanyak 14 (35,9\%) pegawai. Hasil uji statistic dengan menggunakan chi-square diperoleh $p$ value $=0,013$ karena $p$-value $<0,05$ maka hipotesis dinyatakan diterima berarti ada hubungan antara jenis kelamin dengan Sick Building Syndrom pada pegawai Gedung Menara UMI.

Berdasarkan pegawai dengan kelompok umur $\geq 45$ tahun yang mengalami SBS sebanyak 21 pegawai $(46,7 \%)$ dan tidak mengalami SBS 24 pegawai $(53,3 \%)$, sedangkan untuk kelompok umur $<45$ tahun yang mengalami SBS sebanyak 24 pegawai $(52,2 \%)$ dan tidak mengalami SBS sebanyak 22 pegawai $(47,8 \%)$. Hasil uji statistic dengan menggunakan chi-square diperoleh $p$ value $=0,376$ karena $p$-value $>0,05$ maka hipotesis dinyatakan ditolak berarti tidak ada hubungan antara umur dengan Sick Building Syndrom pada pegawai Gedung Menara UMI.

Pegawai dengan masa kerja $<1$ tahun yang mengalami SBS sebanyak 4 pegawai $(44,4 \%)$ dan tidak mengalami SBS 5 pegawai $(55,6 \%)$, sedangkan untuk masa kerja $\geq 1$ tahun yang mengalami SBS sebanyak 41 pegawai $(50,0 \%)$ dan tidak mengalami SBS sebanyak 41 pegawai $(50,0 \%)$. Hasil uji statistic dengan menggunakan chi-square diperoleh nilai $p$-value $=0,514$ karena nilai $p$-value $>0,05$ maka hipotesis dinyatakan ditolak berarti tidak ada hubungan antara masa kerja dengan Sick Building Syndrom pada pegawai Gedung Menara UMI.

Berdasarkan pegawai dengan merokok yang mengalami SBS sebanyak 8 pegawai $(42,1 \%)$ dan tidak mengalami SBS 11 pegawai $(57,9 \%)$, sedangkan untuk tidak merokok yang mengalami SBS sebanyak 37 pegawai $(51,4 \%)$ dan tidak mengalami SBS sebanyak 35 pegawai $(48,6 \%)$. Hasil uji statistic dengan menggunakan chi-square diperoleh nilai $p$-value $=0,323$ karena nilai $p$-value $>0,05$ maka hipotesis dinyatakan ditolak berarti tidak ada hubungan antara merokok dengan Sick Building Syndrom pada pegawai Gedung Menara UMI.

Berdasarkan variabel kondisi psikososial menunjukkan bahwa pegawai dengan kondisi psikososial baik yang mengalami SBS sebanyak 45 responden $(49,5 \%)$ dan tidak mengalami SBS 46 pegawai $(50,5 \%)$, sedangkan untuk kondisi psikososial buruk semua responden tidak mengalami SBS. Hasil uji statistic dengan menggunakan chi-square tidak diperolah $p$ value. maka hipotesis dinyatakan ditolak berarti tidak ada hubungan antara kondisi psikososial dengan Sick Building Syndrom pada pegawai Gedung Menara UMI.

Berdasarkan pegawai yang ergonomi tidak normal dan mengalami SBS sebanyak 32 pegawai $(61,5 \%)$ dan tidak SBS sebanyak 20 pegawai $(38,5 \%)$, sedangkan untuk pegawai yang ergonomi normal, mengalami SBS sebanyak 13 pegawai $(33,3 \%)$ dan yang tidak mengalami SBS sebanyak 26 pegawai $(66,7 \%)$. Hasil uji statistic dengan menggunakan chisquare diperoleh nilai $p$-value $=0,007$ karena $p$ value $<0,05$ maka hipotesis dinyatakan diterima 
Jurnal Sulolipu : Media Komunikasi Sivitas Akademika dan Masyarakat

Vol. 20 No. 12020

e-issn : 2622-6960, p-issn : 0854-624X

berarti ada hubungan antara ergonomi dengan Sick Building Syndrom pada pegawai Gedung Menara UMI.

\section{ANALISIS MULTIVARIAT}

Hasil analisis multivariat untuk melihat variabel yang paling berpengaruh dengan kejadian Sick Building Syndrom pada pegawai di Gedung Menara UMI Kota Makassar, maka selanjutnya akan dilakukan uji regresi logistic multivariate dengan metode enter untuk melihat pengaruh antara variabel independen secara simultan (bersama-sama) dengan variabel dependen dan variabel independen yang paling besar pengaruhnya terhadap variabel dependen.

Variabel jenis kelamin $(p=0,009)$, sedangkan variabel ergonomi $(p=0,005)$, yang memilik nilai $p<0,05$, yang berarti secara statistik variabel ergonomi memiliki hubungan paling besar dengan nilai $p=0,005$ terhadap kejadian Sick Building Syndrom pada pegawai di Gedung Menara UMI Kota Makassar. Berdasarkan hasil tersebut dapat dilihat bahwa model akhir persamaan regresi linier berganda, variabel ergonomi memiliki pengaruh paling tinggi dari variabel jenis kelamin dengan nilai exp(B) sebesar 3.856.

\section{Persamaan Regresi Linier Berganda}

Dari hasil analisis perhitungan dengan program SPSS maka diperoleh hasil persamaan regresi sebagai berikut:

$Y=\beta o+\beta 1 X 1=\beta 2 X 2+e$

Dimana :

$\begin{array}{ll}\mathrm{Y} & =\text { Sick Building Syndrom } \\ \mathrm{Bo} & =\text { Intercept atau konstan } \\ \beta 1, \beta 2 & =\text { Koefisien regresi } \\ \mathrm{X} 1 & =\text { Koefisien untuk jenis kelamin } \\ \mathrm{X} 2 & =\text { Koefisien untuk ergonomi } \\ e & =\text { Error }\end{array}$

$Y=-116+-1,250 X 1+1,350 X 2$

Dari analisis regresi diatas dapat dijelaskan bahwa :

1. Nila konstan sebesar -116 dan negatif dapat diartikan bahwa nilai Sick Building Syndrom sebelum dipengaruhi variabel independen (jenis kelamin dan ergonomi) adalah negatif, tapi umumnya nilai konstata yang negative bukan menjadi alasan untuk menyimpulkan bahwa persamaanya salah (Rietveld dan Sunaryanto, 1994).

2. Koefisien regresi $X 1$ sebesar $-1,250$ menyatakan bahwa jika jenis kelamin tinggi atau meningkat atau di tingkatkan sedangkan variabel lain tetap (konstan) maka Sick Building Syndrom) akan meningkat

3. Koefisien regresi $\mathrm{X} 2$ sebesar 1.350 menyatakan bahwa faktor ergonomi tinggi atau meningkat sedangkan variabel lain tetap (konstan) Sick Building Syndrom) akan meningkat

\section{PEMBAHASAN}

1. Jenis Kelamin

Jenis kelamin adalah ciri fisik dan biologis yang dimiliki oleh responden yang membedakan laki-laki dan perempuan. Jenis kelamin mempengaruhi tingkat kelelahan risiko otot, hal ini terjadi karena secara fisiologis kemampuan otot wanita lebih rendah dari pada pria. Menurut Tarwaka (2011) jenis kelamin laki-laki lebih besar mempunyai kekuatan fisik dibanding perempuan. Hasil penelitian didapatkan nilai $p$-value $=0,013<0,05$ yang berarti ada hubungan yang bermakna. Hasil penelitian ini sejalan dengan pernyataan Rahman (2013) yaitu jenis kelamin laki-laki lebih banyak mengalami keluhan sick building syndrome. Ini dikarenakan oleh beberapa faktor antara lain moyoritas jenis kelamin laki-laki dari 91 responden di gedung menara UMI, dan memiliki aktifitas merokok sehingga rentan terhadap keluhan Sick Building Syndrom.

2. Umur

Hasil penelitian diperoleh bahwa nilai $p$ value $=0,376>0.05$ yang berarti nilai tidak ada hubungan yang bermakna tetapi dilihat dari hasil analisis bahwa umur $\geq 45$ tahun lebih sedikit mengalami SBS dengan nilai $21(46,7 \%)$ di banding dengan $<45$ lebih banyak mengalami SBS dengan nilai $24(52,2 \%)$. Hasil penelitian ini sejalan dengan penelitian yang dilakukan oleh Ramlah (2008) di Kantor Pusat BOSOWA Group Kota Makassar, dimana dari hasil penelitian menunjukkan bahwa responden dengan kategori umur mudalah yang lebih beresiko terhadap SBS.

3. Masa kerja

Hasil penelitian menunjukkan bahwa nilai $p$-value $=0,514>0.05$ yang berarti nilai tidak ada hubungan yang bermakna tetapi dilihat dari hasil analisis bahwa masa kerja $\geq 1$ tahun lebih banyak yang mengalami SBS dengan nilai $41(50,5 \%)$ di banding lama kerja $<1$ tahun dengan nilai 4 $(44,4 \%)$. Hal ini dapat terjadi karena dengan masa kerja yang terlalu lama kemungkinan para pekerja sudah terbiasa dan berpengalamn dengan kondisi lingkungan sekitar tempat bekerja yang ada, sehingga tetap mapu bekerja. Penelitian ini sesuai dengan penelitian yang dilakukan oleh Laila (2011) bahwa tidak ada hubungan antara masa kerja dengan kejadian Sick Building Syndrom 
(SBS) pada pegawai di Gedung Rektorat UIN Syarif Hidayatullah Jakarta 2011. Penelitian lain yang tidak sesuai dengan penelitian (Annisa 2014) masa kerja dengan keluhan SBS semakin lama pegawai bekerja disuatu tempat, semakin besar kemungkinan mereka terpapar oleh faktor-faktor lingkungan kerja baik fisik maupun kimia yang dapat menimbulkan gangguan kesehatan atau penyakit akibat kerja khususnya SBS yang pada akhirnya dapat mengakibatkan menurunnya produktivitas kerja seseorang pegawai atau pekerja.

4. Merokok

Pada kebiasaan merokok presentase terbesar menunjukkan bahwa responden yang tidak merokok lebih besar dibanding dengan responden yang merokok. Hasil analisis menunjukkan bahwa $p$-value = $0,323>0,05$ yang berarti tidak ada hubungan yang bermakna. Responden yang tidak memiliki kebiasaan merokok (perokok pasif) lebih beresiko dibandingkan dengan yang merokok pada penelitian ini disebabkan karena terdapat paparan asap rokok. Sebagai pencemar dalam ruang, asap rokok merupakan bahan pencemar yang biasanya mempunyai kualitas paling banyak dibandingkan bahan pencemar lainnya. Asap rokok menghasilkan polutan di udara dengan melepaskan lebih dari 4000 bahan kimia termasuk didalamnya nikotin, karbon monoksida, formaldehid, benzene dan lainlain, selain itu perokok pasif lebih sensitif terhadap karbon monoksida. Dalam jumlah tertentu asap rokok dapat mengganggu bagi kesehatan, seperti: mata pedih, timbul gejala batu-batuk, pernafasan terganggu, dan sebagainya (Dian, dkk, 2012). Hasil ini sejalan dengan penelitian yang dilakukan oleh Rut (2009) yang menyatakan bahwa faktor kebiasaan merokok tidak terbukti berkaitan degan SBS. Selain itu tingginya persentase penderita Sick Building Sindrome (SBS) dari kalangan perokok pasif pada penelitian ini disebabkan karena jumlah responden yang tidak merokok jauh lebih tinggi.

5. Kondisi Psikososial

Hasil penelitian menunjukkan bahwa presentase $100 \%$ untuk kondisi psikososial pada Gedung Menara UMI, sehingga $p$-value $=0,323>0,05$ yang berarti tidak ada hubungan yang bermakna. Penelitian ini sejalan dengan Laila (2011) menyatakan bahwa gangguan-gangguan kesehatan tipikal
SBS lebih banyak disebabkan oleh kondisi bangunan dan faktor alat didalam kantor.. Penelitian Anis (2004) menyatakan bahwa keluhan-keluhan SBS juga di pengaruh oleh faktor di luar lingkungan, seperti problem pribadi, pekerjaan dan psikologis yang dianggap mempengaruhi kepekaan seseorang terhadap SBS. selain itu menurut Wiwien (2012) faktor individu akan mempengaruhi timbulnya gejala stress karena pekerjaan dan faktor psikososial juga mempengaruhi timbulnya SBS. Stress merupakan gabungan antara beban kerja kantor dengan lingkungan social dan faktor ini dapat memberikan fenomena fisiologis maupun psikologis. Kuantitas kerja dapat menghambat kenyamanan bekerja dan berperan pada iritasi mukosa dan keluhan umum lainnya.

6. Ergonomi

Hasil penelitian menunjukkan bahwa responden yang posisi ergonominya tidak normal dan menderita SBS lebih banyak yaitu dengan hasil 32 responden $(61,5 \%)$ di banding responden yang posisi ergonominya tidak normal yaitu dengan hasil 13 responden $(33,3 \%)$, sehingga didapatkan $p$-value $=0,007<0,05$ yang berarti ada hubungan yang bermakna antara ergonomi dengan Sick Building Syndrom di Gedung Menara UMI. Hasil penelitian ini sejalan dengan dr. Nusye Zamsiar, MS, SpoK (2016) terdapat empat faktor dari Sick Buiding Syndrom, yaitu faktor fisik, psikososial, kimia, dan ergonomi. Untuk faktor ergonomi adalah tata kerja dan juga alat yang digunakan seperti posisi kerja,posisi duduk, dan kursi yang digunakan pegawai haruslah yang nyaman dan alat kerja yang aman. Sikap duduk yang benar yaitu sebaiknya duduk dengan punggung lurus dan bahu berada dibelakang serta bokong menyentuh belakang kursi. Caranya duduk diujung kursi dan bungkukkan badan seolah terbentuk huruf $\mathrm{C}$. setelah itu tegakkan badan buatlah lengkungan tubuh sebisa mungkin. Tahan untuk beberapa detik kemudiann lepaskan posisi tersebut secara ringann (sekitar 10 derajat). Posisi duduk inilah yang terbaik. Duduklah dengan lutut setinggi atau sedikit lebih tinggi panggul (gunakan penyangga kaki) dan sebaiknya kedua tungkai tidak saling menyilang. Jaga agar kedua kaki tidak menggantung dan hindari duduk dengan posisi yang sama dari 20-30 menit. Selama duduk, istirahatkan siku dan 
lengan pada kursi, jaga bahu tetap rileks (Eko Nurmianto, $2008: 114$ ).

\section{KESIMPULAN DAN SARAN KESIMPULAN}

Hasil penelitian tentang analisi faktor demografi dan ergonomi terhadap kejadin Sick Building Syndrom di Gedung Menara UMI Kota Makassar, maka dapat disimpulkan bahwa yang mengalami keluhan Sick Building Syndrom yaitu sebanyak 45 (49,5\%) dan yang tidak mengalami keluhan sebanyak $46(50,5 \%)$, dan di peroleh hasil :

1. Jenis kelamin laki-laki lebih banyak menderita SBS dibanding perempuan. Hasil penelitian didapatkan nilai $p=$ $0,013<0,05$ yang berarti ada hubungan yang bermakna. Hasil penelitian jenis kelamin laki-laki yang mengalami SBS sebanyak 20 reponden $(38,5 \%)$ dan jenis kelamin wanita tidak mengalami SBS sebanyak 25 pegawai $(64,1 \%)$

2. Hasil penelitian diperoleh bahwa nilai $p=0,376>0.05$ yang berarti nilai tidak ada hubungan yang bermakna tetapi dilihat dari hasil analisis bahwa umur $\geq 45$ tahun lebih sedikit mengalami SBS dengan nilai $21 \quad(46,7 \%)$ di banding dengan $<45$ lebih banyak mengalami SBS dengan nilai 24 $(52,2 \%)$.

3. Hasil penelitian menunjukkan bahwa nilai $p=0,514>0.05$ yang berarti nilai tidak ada hubungan yang bermakna tetapi dilihat dari hasil analisis bahwa masa kerja $\geq 1$ tahun lebih banyak yang mengalami SBS dengan nilai 41 $(50,5 \%)$ di banding lama kerja $<1$ tahun dengan nilai $4(44,4 \%)$.

4. Pada kebiasaan merokok presentase terbesar menunjukkan bahwa pegawai yang tidak merokok lebih besar dibanding dengan pegawai yang merokok. Hasil analisis menunjukkan bahwa nilai $p=0,323>0,05$ yang berarti tidak ada hubungan yang bermakna.

5. Hasil penelitian menunjukkan bahwa presentase $100 \%$ untuk kondisi psikososial pada Gedung Menara UMI, sehingga nilai $p=0,323>0,05$ yang berarti tidak ada hubungan yang bermakna.

6. Hasil penelitian menunjukkan bahwa pegawai yang posisi ergonominya tidak normal dan menderita SBS lebih banyak yaitu dengan hasil 32 responden $(61,5 \%)$ di banding pegawai yang posisi ergonominya tidak normal yaitu dengan hasil 13 responden $\quad(33,3 \%), \quad$ sehingga didapatkan nila $p=0,007<0,05$ yang berarti ada hubungan yang bermakna antara ergonomi dengan Sick Building Syndrom di Gedung Menara UMI.

7. Hasil penelitian yaitu jenis kelamin dan ergonomi memiliki hibungan yang bermakna dengan keluhan sick Building Syndrom.

\section{SARAN}

Sehubungan dengan kesimpulan yang telah diuraikan maka hal ini dapat diajukan sran-saran sebagai berikut :

1. Perlu adanya kewaspadaan pada pegawai yang memiliki umur $<45$ tahun dengan masa kerja $\geq 1$ tahun

2. Bagi pegawai disarankan untuk selalu melakukan peregangan relaksasi ketika keluhan-keluhan Sick Building Syndrom dirasa muncul.

3. Sebaiknya ada larangan untuk merokok dalam ruangan untuk staf karena dapat menurunkan kualitas udara dalam ruang.

4. Sebaiknya pegawai Gedung Menara Universitas Muslim Indonesia lebih memperhatikan posisi bekerjanya agar tercipta posisi kerja yang ergonomic

\section{DAFTAR PUSTAKA}

Anies. 2004. Problem Kesehatan Masyarakat dan Sick Building Syndrome. Jurnal Kedokteran Yarsi, Jakarta.

Annisa. 2014. Pengaruh Iklim Kerja Terhadap Dehidrasi Pada Karyawan Unit Workhsop PT. Indo Acidatama Karanganyar.

Depkes RI, 2004, Ergonomi, Pusat Kesehatan Kerj, Departemen Kesehatan RI.

Dian Yulianti, Mukhtar Ikhsan, Wiwien Heru Wiyono, 2012. "Sick Building Syndrome" Departemen Pulmonologi dan IImu Kedokteran Respirasi, Fakultas Kedokteran Universitas Indonesia-RS Persahabatan, Jakarta, CDK-189/ vol. 39 no. 1. 
Jurnal Sulolipu : Media Komunikasi Sivitas Akademika dan Masyarakat

Vol. 20 No.12020

e-issn : 2622-6960, p-issn : 0854-624X

EPA. 1991. Indoor Air Facts No. 4 Sick Building Syndrome. United States Enviromental Protection Agency

Esi, 2010. Jumlah Koloni Mikroorganisme Udara Dalam Ruang Dan Hubungannya Dengan Sick Building Syndrome (SBS) Pada Pekerja B2TKS BPPT Di Kawasan Puspitek. FKM UI. Depok

Eko Nurmianto 2003,, Ergonomi Konsep Dasar dan Aplikasinya, Surabaya: Guna Widya, Edisi Kedua. 2008.

Guntoro, Heru. 2008. Sick Building Syndrome Penyakit Bisa Bersumber dari Kantor. IAKMI.

Laila, N. N., 2011. Faktor-Faktor Yang Berhubungan Dengan Keluhan Sick Building Syndrome (SBS) Pada Pegawai di Gedung Rektorat Universitas Syarif Hidayatullah Jakarta Tahun 2011. Skripsi. Universitas Islam Negeri Syarif Hidayatullah. Jakarta

Nasri, M Sjahrul, Fatma Lestari, Doni Hikmat, 1998, Internal dan Pengendalian Teknik Kualitas Udara Lingkungan Kerja Gedung Bertingkat, Fakultas Kesehatan Masyarakat Universitas Indonesia, Depok.

Nusye. E. Zamsiar , 2016.Ketua Umum Perhimpunan Spesialis Kedokteran Okupsi Indonesia (PERDOKI).

Rahman. Habibi. 2013. Studi Tentang Keluhan Sick Building Syndrom (SBS) Pada Pegawai Di Gedung Rektoran Universitas Hasanuddin Makassar.

Ramlah. 2009, Studi Tentang Keluhan Sick Building Syndrome (SBS) Pada Karyawan Di Kantor Pusat Bosowa Group Kota Makassar Tahun 2008. Skripsi. Fakultas Kesehatan Masyarakat Universitas Hasanuddin Makassar.

Ruth, Safira. 2009. Gambaran Kejadian Sick Building Syndrome (SBS) dan Faktor-faktor Yang Berhubungan Pada Karyawan PT Elnusa Tbk di Kantor Pusat Graha Elnusa. Skripsi. Universitas Indonesia Depok.

Spengler, Samet. 2003. Indoor Environmental and Health: Moving Into the 21st Century, Reviewing the evidence series. American Journal of Public Health vol. No.9. September 2003. http://www.pubmedcentral.nih.gov/picrender.fegi?artid=1740708\&blobtype=pdf.

Tarwaka, Revisi Edisi II. Ergonomi Industri. Dasar-dasar Pengetahuan Ergonomi dan Aplikasi Di Tempat Kerja. 